\title{
TEORETSKI IN METODOLOŠKI PROBLEMI EVALVACIJE POLITIKE IZOBRAŽEVANJA ODRASLIH Ocena doktorskega dela Simone Šinko
}

Z doktorsko disertacijo Simone Šinko je andragoška stroka dobila poglobljeno razpravo za premislek o vrednotenju politike izobraževanja odraslih in hkrati pomemben prispevek $\mathrm{k}$ razvoju stroke. Disertacija »Teoretski in metodološki problemi evalvacije politike izobraževanja odraslih« izhaja iz teze, da »lahko evalvacija politike izobraževanja odraslih pomembno prispeva k povečanju demokratičnosti oblikovanja in izvajanja politike izobraževanja odraslih«. Zaradi izredne kompleksnosti in heterogenosti področja izobraževanja odraslih, ki vključuje tako formalne, neformalne kot priložnostne vrste izobraževanja, se je avtorica odločila svojo osnovno tezo preverjati na področju formalnega izobraževanja, ki vodi k dvigu izobrazbene stopnje odraslih. Ko je zastavila hipotezo in delovne hipoteze, to je bilo leta 2011, je delež javnih sredstev za področje formalnega izobraževanja odraslih (za dvig izobrazbene ravni) znašal 25 odstotkov vseh državnih (proračunskih) sredstev za izobraževanje odraslih. Paradoksalno država štiri leta kasneje, to je leta 2015, temu prednostnemu področju namenja le še tri odstotke vseh proračunskih sredstev, namenjenih za izobraževanje odraslih, čeprav naj bi ta delež v skladu s cilji Resolucije o nacionalnem programu izobraževanja odraslih za obdobje 2013-2020 znašal 20 odstotkov. Večina javnih sredstev je namenjena kratkotrajnim oblikam usposabljanja za potrebe trga dela, tj. pridobivanju kratkoročnih spretnosti/veščin in hitro zastarelih in zamenljivih kompetenc. Zaradi dejstva, da država krči sredstva za dvig izobrazbene ravni in poglobljeno pridobivanje znanja odraslih, je disertacija zelo aktualna, hkrati tudi dragocena, saj opozarja na pomembnost daljših, formalnih oblik izobraževanja, ki dejansko razširijo socialne in ekonomske možnosti posameznika ter dolgoročno zmanjšajo njegovo odvisnost od mezdnega dela in tržnih sil, s čimer se lahko izboljša tudi posameznikova dolgoročna socialna varnost.

Teoretski sklop disertacije je razdeljen v štiri poglavja, v katerih avtorica poglobljeno obravnava značilnosti javne politike, posebnosti javne politike izobraževanja odraslih ter teoretske in metodološke probleme evalvacij politik izobraževanja odraslih. Analiza problematike evalvacije politike izobraževanja odraslih je v teoretskem sklopu interdisciplinarno zasnovana, saj je osvetljena iz politoloških, andragoških in metodoloških perspektiv. Poudarek je na kritičnih teorijah družbe, analizah javnih politik in kritičnih pristopih k izobraževanju odraslih. Pri tem avtorica poudari, da izhaja iz opredelitve politike izobraževanja 
odraslih kot javne politike (v pomenu »public policy«), v pomenu obravnave političnih institucij (v pomenu »polity«) in v pomenu politike kot boja za moč (v pomenu »politics«). Teoretske opredelitve javne politike so predstavljene z vidika marksizma, kritične teorije, socialne demokracije, liberalizma in neoliberalizma, biopolitike, kozmopolitske demokracije in v okviru koncepta javnopolitičnih omrežij. Značilnosti javnopolitičnega procesa so obravnavane $\mathrm{z}$ vidika procesualnosti oblikovanja javnih politik, obravnavanja moči in razmerij med vladanimi in vladajočimi $\mathrm{v}$ javnopolitičnih procesih, javnopolitičnih instrumentov in razvoja analize javnih politik. V poglavju o izobraževanju odraslih in javni politiki avtorica opredeli področje in načine oblikovanja ter delovanja javne politike izobraževanja odraslih v kompleksnih, dinamičnih in raznolikih družbenopolitičnih sistemih. Pojasni pravnoformalno, institucionalno in javnofinančno vlogo države in vlogo nadnacionalnih institucij v politiki izobraževanja odraslih.

V poglavju o teoretskih problemih evalvacij politik izobraževanja odraslih so predstavljeni osnovni pojmi in teoretske paradigme $\mathrm{v}$ evalvacijskem raziskovanju, ki pomembno določajo izbor metodoloških pristopov posamezne evalvacijske študije na določenem področju. Teoretska izhodišča posamezne evalvacije namreč določajo namene, cilje in predpostavke evalvacije, od katerih je odvisen prispevek evalvacije k demokratičnosti določenega področja. Posebna pozornost je namenjena opredelitvi demokratično orientiranih evalvacij, ki izhajajo predvsem iz konstruktivizma, interpretivizma, kritične teorije družbe ter razumevanja demokracije kot deliberativne in participativne. $\mathrm{V}$ okviru demokratično orientiranih evalvacij je razvit poseben pristop $\mathrm{k}$ evalvaciji in raziskovanju, za katerega je značilna vrednotna, participativna, pedagoška in akcijska usmerjenost. Pri tem avtorica opozori na družbenokritične teorije, ki poudarjajo pomembno vlogo evalvacije pri zagotavljanju demokratičnosti javnopolitičnega procesa, in ugotavlja, da je doseganje tega ideala težavno delo, saj zahteva obvladovanje načrtovanih in nenačrtovanih učinkov, različnih družbenopolitičnih, ekonomskih in zgodovinskih kontekstov ter hkrati razumevanje in razkrivanje nepravičnih družbenih praks.

Poglavje o metodoloških problemih evalvacij vključuje izbrane metodološke dileme (kako meriti učinke javnih politik, kako nevtralizirati vpliv ter moč posameznih interesnih skupin, kako zbirati podatke ipd.), ki izhajajo iz teoretskih opredelitev evalvacijskih raziskovanj in javne politike izobraževanja odraslih. Na temelju ontoloških in epistemoloških predpostavk evalvacijskega raziskovanja avtorica problematizira kakovost tega raziskovanja in poudari pomen veljavnosti, kredibilnosti in neodvisnosti evalvacij, ki prispevajo k razvoju demokracije. Na koncu poglavja razčleni različne tipe uporabe evalvacijskih rezultatov, hkrati pa opozori tudi na možnosti zlorabe evalvacijskih spoznanj.

$\mathrm{V}$ empiričnem delu disertacije avtorica $\mathrm{z}$ uporabo kvantitativnih in kvalitativnih metod raziskuje evalvacijo (metaevalvacijo) javne politike izobraževanja odraslih na področju dviga izobrazbene ravni v Sloveniji. S pomočjo analitično deskriptivne in analitično interpretativne metode je na temelju različnih dokumentov (zakonodaja, statistični podatki, nacionalni programi izobraževanja odraslih, rezultati raziskav in evalvacij) analizirala obstoječo politiko formalnega izobraževanja. Pozornost je namenila vsebini, obsegu in glavnim strateškim usmeritvam ter pravnoformalni, institucionalni in finančni vlogi države. Ta del raziskovanja 
je sklenila s pregledom značilnosti oblikovanja in izvajanja formalnega izobraževanja odraslih v Sloveniji. Trenutno stanje evalvacije formalnega izobraževanja odraslih v Sloveniji je raziskala s pomočjo polstrukturiranih intervjujev, ki jih je izvedla $\mathrm{z}$ oblikovalci politik in evalvatorji. Intervjuji so vključevali vprašanja o raziskavah izobraževanja odraslih za dvig izobrazbene ravni, metodoloških problemih $\mathrm{v}$ že izvedenih evalvacijah in o vlogi evalvacije pri zagotavljanju demokratičnosti.

Na podlagi rezultatov raziskave Simona Šinko v sklepu empiričnega dela disertacije predlaga evalvacijski model za vrednotenje politike izobraževanja odraslih, ki se nanaša na dvig izobrazbene ravni prebivalstva. Predlagani model temelji na vrednotah družbene pravičnosti, enakosti možnosti in spreminjanja družbenih razmerij v korist tistih z manj moči. Kot pogoj uspešne evalvacije politike formalnega izobraževanja odraslih avtorica postavi v ospredje poznavanje in upoštevanje različnih teoretskih izhodišč in praktičnih kontekstov. Vzpostaviti in zagotavljati je treba sistematično spremljanje izvajanja politike izobraževanja odraslih in pri tem upoštevati značilnosti te politike. Pomembni deli predlaganega modela so izbira ustrezne metodologije, vključitev različnih interesnih skupin, objavljanje in uporaba rezultatov evalvacije, interdisciplinarno sestavljena evalvatorska skupina in medresorsko povezovanje.

V sklepnem delu disertacije avtorica preverja izhodiščno tezo in jo delno potrdi. Na temelju teoretskega in empiričnega proučevanja sklepa, da ima evalvacija politike izobraževanja odraslih potencial, da pripomore k povečanju demokratičnosti oblikovanja in izvajanja politike izobraževanja odraslih, če izpolnjuje prvine predlaganega modela. Ugotavlja, da na področju politike formalnega izobraževanja odraslih v Sloveniji nimamo vzpostavljenega celovitega sistematičnega spremljanja in evalviranja rezultatov ter učinkov politike izobraževanja odraslih za dvig izobrazbene ravni, ki bi lahko spodbujalo družbeno pravičnost in spreminjanje družbenih razmerij v korist tistih z manj moči. Prav tako ni pregleda nad tem, kolikšna je uporaba rezultatov evalvacije in kakšen vpliv imajo izvedene evalvacije na nadaljnje oblikovanje in izvajanje politik. Intervjuji z oblikovalci politik in evalvatorji politike izobraževanja odraslih so pokazali manko predvsem v vključevanju interesnih skupin v evalvacijo, pomanjkljivosti in nesistematičnost obstoječih baz podatkov in zelo skromno uporabo rezultatov evalvacij.

Disertacija je pomemben prispevek h konceptualnim opredelitvam politike izobraževanja odraslih ter k teoretski in metodološki utemeljitvi evalvacije politike izobraževanja odraslih. Poleg tega lahko rezultati disertacije služijo za izhodišče implementacije evalvacij na drugih segmentih javne politike izobraževanja. Posebna kvaliteta disertacije je njena interdisciplinarnost, saj avtorica pravilno ugotavlja nujnost mnogostranskega pristopa in osvetlitve kompleksne problematike iz različnih perspektiv. Pomembna je tudi za širše družboslovno področje, saj avtorica na nekaterih točkah sega prek meja dosedanjih pedagoških in andragoških spoznanj. 